\title{
Narrating political opportunities: explaining strategic adaptation in the climate movement
}

\author{
Joost de Moor ${ }^{1} \cdot$ Mattias Wahlström ${ }^{2}$
}

Published online: 13 April 2019

(C) The Author(s) 2019

\begin{abstract}
This article advances theory on social movements' strategic adaptation to political opportunity structures by incorporating a narrative perspective. Our theory explains how people acquire and use knowledge about political opportunity structures through storytelling about the movement's past, present, and imagined future. The discussion applies the theory in an ethnographic case study of the climate movement's mobilization around the UN Climate Summit in Paris, 2015. This analysis demonstrates how a dominant narrative of defeat about the prior protest campaign in Copenhagen, 2009 shaped the strategizing process. While those who experienced Copenhagen as a success preferred strategic continuity, those who experienced defeat developed a "Copenhagen narrative" to advance strategic adaptation by projecting previously experienced threats and opportunities onto the Paris campaign. Yet by relying on a retrospective narrative, movement actors tended to overlook emerging political opportunities. We demonstrate that narrative analysis is a useful tool for understanding the link between structure and agency in social movements and other actors affected by (political) opportunity structures.
\end{abstract}

Keywords Climate change Narrative Political opportunity structure $\cdot$ Social movements . Strategy $\cdot$ Structure and agency

How do social movements adapt their strategies to political opportunity structures (POSs)? This is one of the most cited questions in social movement research and goes right to the heart of how movements advance social change. However, it is also one of

Joost de Moor

joost.demoor@statsvet.su.se

Mattias Wahlström

mattias.wahlstrom@gu.se

1 Stockholm University, Universitetsvägen 10F, 11418 Stockholm, Sweden

2 Department of Sociology and Work Science, University of Gothenburg, Box 720, 405

30 Gothenburg, Sweden 
the least settled questions and it is ultimately connected to the thorny theoretical challenge of unravelling the relationship between structure and agency (Koopmans 2004; Walgrave and Verhulst 2009). A common assumption is that the POS is perceived by movement actors, who subsequently adjust their strategies accordingly (e.g., Meyer and Staggenborg 1996). There is some evidence to support this idea, yet it is far from conclusive (de Moor 2016a). To advance this debate, we propose a new model that combines the "perception hypothesis" with insights from narrative analysis, which has remained largely detached from structural approaches like POS theory. Specifically, we argue that while movement actors may perceive, and adapt to, structural features of the political context, these activities take place within wider processes in which social movements construct stories about themselves in relation to their environment, as well as their history, presence, and projected future.

Our model assumes that strategic adaptation to POSs through narratives unfolds in three phases. Firstly, social movements acquire knowledge about contextual threats and opportunities through experiencing interactions with the political context. In a second phase, past "experiencing" is retained in memory as narrated "experiences." In the third phase, movements draw on these experiences, and the knowledge about threats and opportunities embedded within them, to inform their strategic decision-making process. How "experiencing" is turned into a narrative of "experiences" is by now fairly well studied in existing narrative analyses of social movements (for an overview, see Polletta and Gardner 2015). In contrast, how narratives are used and revisited for strategizing, especially by identifying signs of threats and opportunities within them, has remained understudied. This article addresses this lacuna.

Analyzing strategic adaptation to POSs through narrative analysis has several key benefits. It helps us appreciate that one must understand narration about the political context in relation to other functions narratives fulfill, such as the development of a collective identity. Narrated opportunities must fit the wider stories movements tell about themselves. Understanding perceived POSs in this way explains how responses to it are shaped by more than strictly utilitarian calculations. Importantly, this helps explain why some narratives outweigh others and why some opportunities are sometimes not responded tosomething extant theories have been insufficiently capable of doing.

We apply our model to an ethnographic case study of the climate movement's historic mobilization for the COP21 UN Climate Summit in Paris, in 2015. Through observations, interviews, and document analysis we were able to develop a profound understanding of the collective construction of narrative, opportunity, and strategy. The exceptionally broad coalition driving the movement's mobilization ensured that we could directly observe intense, defining strategic negotiations. Since the COP21 mobilization was part of a long line of well-documented climate summit mobilizations, we were able to examine closely how experience and tradition shaped strategic adaptation, while also assessing how relevant changes in the political context were processed. We show that the narrated experience of the Copenhagen Climate Summit of 2009 was essential for the formulation of new protest strategies. We conclude by summarizing how our model can inform structure-agency debates within and beyond social movement studies. 


\section{How political opportunity structures matter}

The POS approach has been identified as one of the most influential perspectives in social movement research (Giugni 2009; Hutter 2014; McAdam and Boudet 2012), yet clear definitions of POS remain scarce. Often preferring operational over theoretical definitions, scholars typically point to the effect of variations in structural features of the political context, across space or over time, which create opportunities for (or threats to) social movements and thereby affect levels of mobilization, degrees of success, and - our focus in this article - strategies (e.g., Goldstone 2004; McAdam 1996; Meyer 2004; Tarrow 2011). Koopmans (1999) presents a rare and convincing attempt at theoretical definition, arguing that opportunities should be conceived as "options for collective action, with chances and risks attached to them that depend on factors outside the mobilizing group" (p. 97). Political opportunities specifically refer to opportunities that relate to the political sphere, as opposed to, e.g., economic opportunities (cf. Wahlström and Peterson 2006). Finally, we talk about POS when the factors that shape these opportunities are structural in the sense that they are outside the scope of immediate change. The POS is a structure for opportunities rather than of opportunities.

The POS comprises input structures, whose "openness" determine social movements' access to a polity, and output structures, whose "strength" determines a polity's ability to get things done (Hutter 2014; Kitschelt 1986; van der Heijden 2006). Input structures include institutional rules about civil society's access to politics, electoral structures that determine minorities' electoral chances, cleavage structures, elite allies, and government's tendency to repress or facilitate challengers (e.g., Kriesi et al. 1995; McAdam 1996). Output structures have received considerably less attention in the literature, but are often related to the absence of veto players, polities' spending power and control over market participants, and, crucially for the current case, (international) governmental organizations' power to develop and enforce legislation (de Moor 2016a; van der Heijden 2006). If a polity is both open to a movement's demands and able to turn demands into political output, substantive success is most likely, and targeting this polity becomes more appealing (de Moor 2016b; Overby 1990).

Space prevents us from doing full justice to the conceptual debate surrounding POS. Yet we believe Koopmans's definition solves some of the main concerns with POS (e.g., Goodwin and Jasper 1999), showing convincingly that "political opportunities provide a link between structure and action" (Koopmans 1999, p. 104). What we are concerned with in this paper are the under-researched processes by which this "link" between the POS and strategic action comes about. More specifically, we aim to understand how activists identify the impact of input and output structures on the outcome of past actions and on chances and risks associated with particular strategies, as well as how such assessments affect forward-looking strategizing.

Such theoretical improvement is necessary. While the basic premise of the POS approach is straightforward and convincing, discrepancies between theory and findings demand a better understanding of causal mechanisms. On the one hand, classic and more recent examples of longitudinal and comparative studies show the effect of variations in POSs over time (McAdam 1982; Tarrow 1989; Tilly 1978) and across space (Eisinger 1973; Kitschelt 1986; Kriesi et al. 1995; Vráblíková 2014). On the other hand, several studies have found no convincing support for the idea that 
variations in the political context affect social movements (for an overview, see Meyer 2004). Some studies also show that political mobilizations, like the immigrant rights movements, the anti-Apartheid movement, the Palestinian Intifada or the Iranian Revolution, emerged under very unfavorable conditions (Alimi 2009; Kurzman 1996; Nicholls 2014; Thörn 2006). Some suggest that a theory that predicts such contradictory results should be rejected (Goodwin and Jasper 1999). We prefer to respond to the more common call for efforts to increase our understanding of the causal mechanisms at work, and the conditions under which they do, or do not, apply (e.g., Koopmans 2004; Meyer and Minkoff 2004; Opp 2009).

\section{Causal assumptions about political opportunity structures and strategic choices}

Meyer (2004) distinguishes between a more and a less reflexive theory linking POSs to movements' strategic choices. From one perspective, movements can be regarded as "consistent champions" who continue their struggle, regardless of opportunities or threats, and strike a tone that resonates with the POS "like the broken clock that correctly tells time twice daily" (Meyer 2004, p. 140). Similarly, Koopmans (2005) suggests that an evolutionary process is responsible for POSs' effect. The political context creates conditions that are more favorable for some "species", increasing chances of survival for some groups or strategies, while forcing out others.

In their purest form, these theories acknowledge no agency of social movements, and Meyer (2004) therefore proposes the alternative idea of "strategic respondents," who become aware of the availability of certain opportunities, experience "cognitive liberation." and respond accordingly (see also McAdam 1982). We call this the "perception hypothesis" (de Moor 2016a, p. 15), which, though rarely studied empirically, ${ }^{1}$ is by far the most commonly assumed explanation for how opportunities affect social movements (e.g., Diani 1996; Klandermans 1997, p. 173; McAdam 1982, p. 48; Meyer and Staggenborg 1996; Opp 2009, p. 180; Tarrow 2011, p. 12). The perception hypothesis assumes a bridgeable duality between real and perceived POSs. In some cases objective elements of the POS may be misread (Kurzman 1996; Suh 2001), but in general, perceptions must be "correct" if the theory is to explain why movement strategies correspond to the POS (e.g., Hutter 2014; Kriesi et al. 1995).

However, the explanatory power of this theory has remained limited because it has not been specified why POSs sometimes would, and other times would not, be perceived and acted upon. Hence, we are challenged to study in more detail the processes through which POSs are perceived and used for strategic adaptation, thereby revealing the causal mechanisms and their conditions at work (Koopmans and Olzak 2004; Opp 2009).

Gamson and Meyer (1996) propose that we should study how opportunities are "framed." which offers a convincing, albeit partial, answer to this challenge. They argue that movements are not unified entities, but rather "fields of actors." These actors have different experiences and goals, and they have diverging strategic preferences. How they perceive and frame opportunities is relative to these qualities, and various

\footnotetext{
${ }^{1}$ Although some have studied the effect of perceived opportunities on political activism (de Moor 2016b; de Moor et al. 2017a; Alimi et al. 2006), it is rarely studied whether or how these perceptions relate to objectively existing elements of the POSs (de Moor 2016a; Suh 2001).
} 
movement actors will thus have more or less diverging interpretations of the POS. Hence a common call to ask "opportunities for whom and for what?" (Hutter 2014; Meyer and Minkoff 2004). Throughout strategic negotiations, such perceived opportunities will often need to be framed (and often exaggerated) to convince fellow organizers or participants of the appropriateness of particular strategies. Importantly, the notion that actors' background determines how they perceive and frame opportunities does not mean that perceptions of POSs are only used to legitimize prior strategic preferences. While it is true that social movements often follow repertoires of action (Tilly 2004), they also change strategies that no longer fit the circumstances, and various studies show how POSs can shape these changes (Meyer 2004).

The emphasis on framing usefully identifies an important part of the process by which social movements respond to POSs. However, it does little in answering why the way in which some opportunities link to the political context is sometimes accurately perceived and responded to, while another time it is not. Firstly, it does not tell us how "real" POSs become perceived, missed, or misinterpreted in the first place; secondly, it remains unanswered why some "framed opportunities" are more successful than others; and thirdly, the relation between framings of POSs and specific strategies is underdeveloped. The three-phase model we propose in this article (summarized in Fig. 1, and further explained in the following subsections) addresses these gaps in Gamson and Meyer's seminal contribution, by shifting attention to the role of experience and narrative.

In the first step in our model, "experiencing" activists learn about the POS through interacting with it. In a second step, "experiencing" becomes "an experience" as actors retrospectively construct a narrative about what happened. At this stage, there are exchanges of individual experiences and possibly negotiations to arrive at joint experiences of groups and organizations. (This is illustrated in the figure by the decreasing number of parallel versions of experiences for each successive step in the model.) In a third step, these narratives are appropriated to inform strategizing. In order to arrive at common strategies within coalitions, further negotiation and streamlining of experiences may be required. In reality, these steps have blurred boundaries and overlap, since experiencing itself may have an inherent narrative structure (Carr 1986) and we expect that narrated experiences can become redefined through strategizing. However, in this article we show that analytically, these steps are useful tools for understanding strategic adaptation.

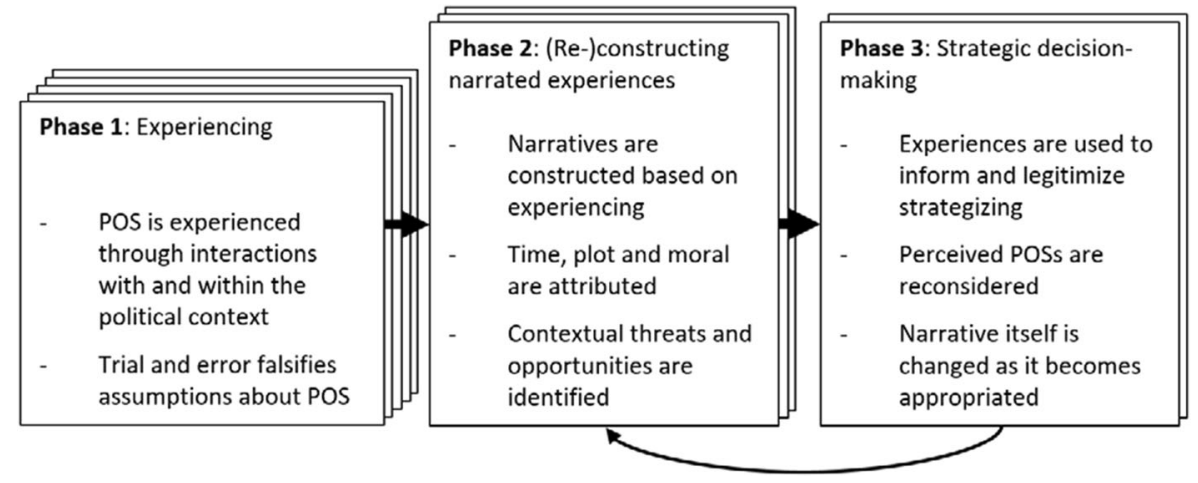

Fig. 1 Three-phase model of strategic adaptation 


\section{Experiencing the political opportunity structure}

The first question our model addresses is thus: where does information about the POS come from? We argue that experiencing is essential here. The perception hypothesis implicitly suggests that knowledge about POSs is derived from carefully studying one's environment. Media are presumably important in this regard, and occasionally activists may consult policy documents (McAdam and Boudet 2012). However, not all POSs will be intelligible in this way, since some are more abstract and not readily interpretable in terms of opportunities (e.g., the proportionality of the electoral system (Kriesi et al. 1995)). More importantly, such information lacks authority because it has not yet been subjected to a process of trial and error (Alimi 2009). What seems to be an opportunity from afar might turn out to be a trap from close by (Jasper 2006, pp. 18-19).

It is more likely, therefore, that interpreting the POS relies on movement actors' use of past experience (Boutros 2017; de Moor 2016a; Koopmans and Olzak 2004). When experience involves multiple actors, reactions from others can provide immediate feedback. Knowledge about POSs is typically gained from reactions from state actors, often channeled through mass media, while reactions from the mass media, bystanders, or online social media provide information about so-called discursive opportunities (Braun and Koopmans 2014; Koopmans and Olzak 2004; Wahlström and Törnberg 2019). This feedback informs actors about the correctness of assumptions that guided the initial engagement with the field. Anticipated opportunities may turn out as accurate or as misconstrued.

Notably, based on Koopmans's (1999) conceptualization of opportunities as options for actions shaped by external factors, and opportunity structures as the structural part of these factors, there is a need to distinguish between perceived opportunities and perceived opportunity structures. Acquiring information about, e.g., a shift in elite alignments (i.e., perceiving POS) is not the same as identifying this as a new potential opportunity for political influence (i.e., perceiving political opportunities). While the former refers to a set of, at least in principle, objectively identifiable properties of the political system, the latter is inherently based on subjective evaluations by actors about what viable options for action these properties open up. Hence, POSs are part of the conditions in which social movements operate, and through the experience of interacting within these conditions, movement actors develop knowledge about contextual threats and opportunities. Those experiences can be first-hand, or passed on between actors (Brown 2016).

\section{Narrative and strategic adaptation in social movements}

We build on insights from narrative analysis in order to define what processes we expect to be relevant in steps two and three of our model, which concern the retention of prior experiences in narrative form and the use of these narrated experiences in strategizing. If opportunities are recognized because of a movement's members experiencing interactions within a political context, they must also be entangled in the movements' wider experiences that feed into their narrative about who they are, where they come from, and where they are going. Strategic adaptation to POSs must thus be understood in the context of the wider functions and characteristics of movement narratives. 
A growing body of research shows that narratives play a crucial part in shaping social movements (J. Davis 2002; Polletta 2006). Fine (1995) even characterizes social movements as "bundles of narratives." Narratives and storytelling have been shown to perform several functions in movements, including mobilization and recruiting (Benford 1993), gaining support for claims (Tatum 2002), commemoration (Armstrong and Crage 2006), internal control (Benford 2002), building collective identity (Daphi 2017; Somers 1994) and for making sense of events (Wahlström 2011). While some stories are specific to individuals or shared only within certain groups, "movement narratives" are shared broadly and as such can have profound impacts on movements' development (Daphi 2017).

The narrative approach fits well into the broader cluster of cultural perspectives on social movements (Johnston and Klandermans 1995) and specifically contributes with analytical tools and insights not provided by related approaches such as frame analysis (Benford and Snow 2000; J. Davis 2002; Polletta 1998, 2006). While narrative analysis and frame analysis both conceptualize how ideas are communicated, they typically look at distinct forms of discourse (informal yet consistent stories as opposed to formal slogans or demands) and narrative analysis also introduces particular analytical sensitivities (Steinberg 1998). Polletta (2006, pp. 6-7) argues that a narrative approach offers a better understanding of persuasion compared to frame analysis, both because of the academic knowledge about narratives' rhetorical qualities, as well as popular intuitive understandings of what constitutes a good story. In other words, while frame analysis, broadly speaking, understands persuasion in terms of discursive content-logical or associational links between various concepts and ideas-narrative analysis also takes into account the persuasive qualities of the form of discourse- how a story structure might provide a compelling packaging of an idea.

Perhaps most importantly in the context of our analysis, a crucial element of a narrative approach is sensitivity to the significance of events and how actors link them over time, which fundamentally differs from how frames structure meaning (Polletta 1998). What sets a narrative apart from a mere enumeration of events in chronological order is the plot, which provides the causal or meaningful links between these events by weaving them together into a story with a beginning, middle, and end. Through the plot, the narrative communicates a more or less explicit moral. These characteristics are well summarized in Polletta and Gardner's (2015, p. 535) definition of narrative as "an account of a sequence of events in the order in which they occurred to make a point."

Fine (1995, p. 134) notes that "stories provide models for appropriate behaviors, as well as identification with the key actors in the movement." Nonetheless, the role of narrative in movement strategizing has so far remained largely overlooked. We address this gap by integrating experience and narrative into our three-phase model about the link between POSs and movement strategies, thereby building on arguments that narrative is a fundamental mode of knowing and reasoning about human action (Bruner 1986; W. R. Fisher 1987; Polkinghorne 1988) that also involves future projections, such as strategizing (Mische 2014). Specifically, in phase two of our model, narratives are constructed about the events experienced in phase one. As events about the collective are told and retold they become part of the collective memory of the movement, consolidating into movement narratives that reinforce the collective identity of the movement (Daphi 2017). These narratives incorporate information about the POS 
and in turn inform narrative-based strategizing in the third phase of our model, which in itself can be considered as prospective narration oriented to action.

Here, we expect to find particular relevance for "narratives of defeat," which have recently been analyzed to make sense of how social movements cope with failures (Beckwith 2015; Hadden 2017). How stories of defeat are interpreted in relation to a more comprehensive narrative about the movement determines the severity of the consequences of defeat for further mobilization. Voss (1998) has argued that the existence of "fortifying myths" make activists less inclined to give way to despair or self-blame after setbacks in their struggle. Presumably, throughout such processes of sense-making, movements also revisit their strategies and how they fit within the POS. Yet existing studies have so far overlooked this element. Narratives of defeat likely prompt a reevaluation of past strategies in order to prevent repeating mistakes. In particular, they provoke reevaluations of the POS, as a defeat may suggest that assumptions about the POS underlying previously chosen strategies were false. Narratives of interaction with the POS are thereby likely to affect reconsiderations of strategies after defeat. By contrast, success may suggest that assumptions about the POS were correct and that continuity is appropriate.

Following this logic, strategizing can be expected to be at least partially based on narrative rationality (W. R. Fisher 1987) as opposed to purely formal rational reasoning, thus explaining why apparent openings in the POS do not automatically trigger strategic responses. Particularly since strategizing is essentially about convincingly communicating strategy to allied individuals and groups (Freedman 2015, pp. 614-615), strategic narratives crucially depend on their narrative probability and narrative fidelity. While the former refers to the extent to which narratives "make sense" as stories, the latter denotes the credibility of a story in the light of a wider existing corpus of narratives movements use to make sense of themselves and their place in society. Hence, narrative probability and narrative fidelity may be what determines the impact of certain perceived political opportunities. This is not to imply that movement actors are irrational. Indeed, social reality presents a complexity that makes case-based narrative knowledge in many ways more useful and convincing for practical action compared to decisions based on probabilities and general laws (Flyvbjerg 2001).

Importantly, we do not argue that activists must constantly tell long, complex stories throughout time-constrained processes of strategizing. Rather, much communication about experiences in social settings occurs in the form of what Bamberg (2004) and Georgakopoulou (2006) term "small stories": short, less developed, and often elliptical snippets of stories. Stories about crucial events are often further abridged to the point of "metonymy," where a story is tacitly implied in communication through a single word or short expression representing a central aspect of it, such as its location ("Seattle") or time ("1968") (Lakoff and Johnson 2008). Metonymical expressions aid in creating singular characters of complex wholes, similar to what Jasper, Young, and Zuern have recently called "character work" (2018). Polletta (2006) adds that apart from economizing discussions, metonymy also comes to indicate what is taken for granted in a movement. Mutual understanding of a metonymical expression signals belonging and common identity, and at the same time makes the taken for granted assumptions behind it very difficult to question. Polletta notes that challenging the associations behind a 
metonymy "can be interpreted as a sign of one's ignorance and possibly one's insecure place in a group" $(2009$, p. 52). As metonyms, narratives about defeats and POSs are therefore likely able to exert even greater influence on strategizing.

\section{Studying the climate movement around COP21}

We demonstrate our theory with an ethnographic case study of the climate movement's mobilization for the COP21 climate change conference in Paris, 2015. ${ }^{2}$ We show how narrative processes shaped the movement's strategic response to the POS of the UN climate process in general and COP2 1 in particular, which presented both opportunities and threats. Some have described the UN's shift from top-down climate governance (e.g., the Kyoto Protocol) to a bottom-up approach that welcomes a broad range of nonstate actors as co-creators of climate governance as an opening-up towards civil society actors (Bäckstrand et al. 2017; de Moor et al. b). Yet while the number of NGO participants to the COP has steadily increased, and while the UN is considered to have relatively favorable institutional provisions for participation compared to other international governmental organizations, many point out serious limitations as well. In particular, less resourceful organizations, including many from the Global South, have more difficulty finding access, and what civil society actors are allowed to do inside COPs is restricted to activities like lobbying or official "side-events" (Müller and Walk 2014; Schaefer Caniglia et al. 2015). Violating codes of conduct has often led to more or less permanent expulsions. Hence, despite some opening up, the COPs input structure is often considered unfavorable towards more critical voices and protestoriented activities. As for its output structure, the UN and the COP have consistently been described as weak - in particular with reference to its inability to enforce binding treaties (Hale et al. 2013; van der Heijden 2006). Many have pointed out the more subtle outcomes of COPs, but in terms of legislation, they have generally failed to live up to expectations. We show that many climate actors developed their perception of the COP's POS by drawing on the narrated experience of the COP15 climate change conference in Copenhagen, 2009. Yet we demonstrate that the application of concurrent conclusions about opportunities in strategizing was more complicated than a consensual response to a "correctly perceived" POS.

The study ran between October 2014 and September 2016, and thus it focuses on the application of the Copenhagen narrative in strategizing for Paris, rather than on its development in the immediate aftermath of COP15. We studied two collaborating coalitions that each brought diverse groups together. Radical grassroots collectives like Reclaim the Power and Earth First! were mainly organized in Climate Justice Action (CJA). ${ }^{3}$ Large NGOs like WWF, Greenpeace, and Friends of the Earth, online based campaign organizations like 350.org and Avaaz, trade unions, and indigenous groups

\footnotetext{
${ }^{2}$ COP21 stands for the 21st Conference of the Parties, of the United Nations Framework Convention on Climate Change (UNFCCC).

${ }^{3}$ Climate Justice Action during COP21 was not the same as during COP15. While there were important similarities in terms of strategic and political views, and some overlaps in membership, the two were distinct. The CJA group around COP21 chose its name in recognition of its similarities with the COP15 CJA group, which no longer existed.
} 
like La Via Campesina and the Indigenous Environmental Network were mainly organized in the larger Coalition Climat 21 (CC21).

Although high profile climate summits had long been crucial moments for global mobilization around climate change (Death 2011; Hadden 2015), it was somewhat surprising that the mobilization for COP21 was so large and so broad (de Moor 2018). Many studies describe that the 2009 Copenhagen mobilization had been widely experienced among activists as a massive failure (Bullard and Müller 2012; D. R. Fisher 2010; Hadden 2014, 2015). The movement had framed COP15 as the last chance to save the planet and invested lots of resources and hope in securing this achievement. When the summit failed, therefore, so did the movement. This created a wave of disappointment, and by extension, demobilization. Within the climate movement, many therefore proposed never to mobilize around climate summits again; never would COPs be able to deliver, and any engagement with them would be a waste of energy. Although once a radical idea, this idea, Hadden (2015) notes, had become increasingly mainstream, and scholars predicted a move of climate activism from the transnational to the local level (Dietz 2014). Yet regardless of their political significance, COPs always present important, if not irresistible, "global public sphere moments" for climate activists (Eide and Kunelius 2010), which in part explains the level and scope of the COP21 mobilizations.

In comparison to the Copenhagen mobilization, the Paris mobilization became characterized by a generalized desire to reduce focus on influencing the official negotiations (for details see, de Moor 2018). Some groups still wanted to put pressure on decision-makers inside the COP. Yet many groups, including ones who in Copenhagen had still aimed to influence the negotiations, now rallied around the idea of "having the last word." This entailed a mobilization that would take place immediately after the summit, symbolizing the organizers' distrust in the process and their condemnation of its expected insufficient outcome. Others even advocated a mobilization that would completely ignore the COP, using the COP's momentum to target other, arguably more powerful actors. A coordinated "call to action" resulted from these mixed preferences, still including a large, "family-friendly" demonstration on the eve of COP21, which aimed to be more influence-oriented, but that was followed by an "escalation" of actions ignoring or condemning the negotiations. This included a plan to disrupt the "Solutions COP21" fair, where corporations could showcase their arguably "false solutions," a weekend-long fair where the movement would display its "real solutions," and the "Red Lines" civil disobedience action, which aimed at symbolically blocking negotiators inside the conference center, preventing them from "releasing their disastrous plans on the world."

The protest strategy was disrupted when two weeks before the COP, Paris was hit by severe terror attacks that left 130 dead. The French state responded by declaring a state of emergency, which included a ban on protesting. Nonetheless, all planned actions ultimately took place, and though they had to be adapted, they largely followed the organizers' initial strategic desires to influence, and above all, condemn or ignore the COP (Wahlström and de Moor 2017).

In our analysis, we dive into the almost two-year long process of intense strategic preparations and negotiations leading up to these actions. Beyond the fact that the climate movement's mobilization for COP21 has been one of the most significant mobilizations of one of the most emblematic social movements of our time, there are 
three main reasons why it provides a particularly appropriate case to address this study's main goals.

Firstly, a major methodological advantage has been that we could have advance knowledge of when and where the mobilization would take place. This made it possible to observe directly strategic decision-making processes. Unfortunately, when the idea for this project emerged in September 2014, several strategic meetings had already taken place. However, we were able to retrieve all official meeting summaries and interviewed participants, and so, we were able to cover the entire campaign and its aftermath.

A second methodological advantage was the breadth of this mobilization. Like in newly emerging social movements, very heterogeneous movements "provide rich material for ethnographic observation because their members detail the logic and rationale for ideas more extensively than do members of more established activist groups, in which such understandings are widely shared and explicit justifications are no longer needed" (Blee 2013, p. 657). These situations create "natural focus groups" in which discussions on theoretically relevant issues can be directly observed.

Thirdly, we aimed to distinguish between responses to knowledge obtained through previous experience and responses to changes in the POS. It was therefore key to analyze a case within a recurring, relatively stable context that also had some dynamic elements. The fact that the climate movement annually returns to the COP meetings allowed organizers to draw on previous experiences in developing new strategies. Yet some changing elements were hardly taken into account because they could not be presented as a narrated experience in the movement's strategic discourse.

COPs stand out from "normal" political situations as "mega-events" (Aykut et al. 2017). Still, this mix of stable and dynamic contextual elements is very common, which indicates that our case study provides generalizable knowledge that can be applied to other social movements and protest campaigns that include series of interactions with governmental bodies, between which activists have sufficient time to strategize.

\section{Data collection}

Theory-driven participant observation has been the empirical backbone of this study (Blee 2013; Lichterman 2002). Using this method, we observed most relevant online and offline meetings of CC21 and CJA between October 2014 and March 2016, including twenty online meetings of about one-two hours and eleven offline international meetings of up to three days (twenty-one days in total). ${ }^{4}$ In addition, we were in Paris during the two weeks of COP21 to observe further strategic meetings, as well as protest actions. This was particularly important to see how original plans were adapted to the situation emerging from the terror attacks two weeks before the summit.

\footnotetext{
${ }^{4}$ We obtained consent for observing the meetings by announcing our presence and aims to the meeting's organizer or facilitator. When they preferred, we would also announce our presence and aims to all participants at the beginning of the meeting. The latter was more often necessary at CJA meetings that were less public, more intimate, and sensitive because transgressive strategies were being discussed. We also guaranteed confidentiality, and offered to answer any questions about the project. We kept these interventions as brief as possible to avoid taking up valuable meeting time. At (plenary) CC21 meetings, the organizers reasoned that because anyone could walk in and listen, so could we.
} 
In addition, we conducted thirty-one semi-structured interviews of one to two hours to tease out further why key actors took certain positions in the meetings we observed. Interviewees were selected based on their participation in observed decision-making processes, and by extension, we ultimately interviewed key representatives of most main organizations participating in this mobilization. Moreover, we also conducted many informal interviews during days of observation.

Finally, by monitoring CC21's and CJA's mailing lists and websites, we had access to important documents as well, including email exchanges, official meeting summaries, and (draft) mobilization materials such as calls to action, flyers, action consensuses, etc. Details about these data are available in the Appendix.

\section{Data analysis}

Our observation about the centrality of the Copenhagen experience in strategizing for COP21 first emerged as an inductive finding. In the first documents that we analyzed, and during the first meetings we observed, references to Copenhagen were frequent, and their central importance for strategic preferences soon became clear. During the early interviews of the project, respondents articulated the centrality of the Copenhagen experience when asked about their strategic preferences, without having been prompted about this specific subject. Since we aimed to understand the strategic decision-making process and the role of the POS therein, we continued to pay attention to references to Copenhagen throughout the following months. In later interviews, we occasionally asked respondents about the role of previous COP meetings in their strategic considerations, triggering further responses about Copenhagen.

In coding our data, we retained this focus on the broader decision-making process and on Copenhagen specifically. Aided by the software NVivo, we coded our data around the broader topics of strategic decision-making, perceived POSs and opportunities, and the relationships among them. We also coded all references to Copenhagen in our data. This allowed us to assess the exact role of the Copenhagen narrative in the wider process of strategic adaptation, while remaining sensitive to the importance of possible alternative explanations.

In our analysis, we have been especially sensitive to (1) the use of "Copenhagen" as a metonym in strategic deliberation between activists and (2) incidences of more or less developed narratives about Copenhagen in interview transcripts, observation notes, and documents, websites, and emails. From the point of view of narrative analysis, we have used a dual strategy. First, we elucidated the content and narrative structure(s) of "Copenhagen stories." Second, we observed the use of these narratives and of the metonym "Copenhagen"" in interaction between activists.

\section{How the Copenhagen narrative shaped the Paris mobilization}

Our analysis focuses on how, moving from the second to the third phase of our model, narrated experiences affect strategizing. As explained above, how experiencing becomes narrated experiences in the first two phases of the model lies outside the empirical scope of our study. The experiencing of Copenhagen has already been described in the many detailed scholarly accounts of that mobilization (e.g., D. R. 
Fisher 2010; Hadden 2015), and though we are not aware of any detailed narrative analyses of how the Copenhagen mobilization was retold in its immediate aftermath, scholars have recounted activist interpretations following the Copenhagen summit (see especially Hadden 2015).

Because our data collection started five years after Copenhagen, we can only contribute with retrospective accounts of these narrative processes. Interviewees told us that because the movement disintegrated after COP15, there was no common reflection on what happened and therefore hardly any narrative streamlining of the experience across the movement took place. Rather, activists expressed frustration with the discordance among groups' reactions to the summit's outcome. As climate activism localized again in the following years, we expect narratives to have developed in local and national contexts. COP19 in Warsaw, held November 2013, is regarded by many activists as a moment of international reunification. To express discontent with that summit's representation of fossil fuel interests, a broad coalition of civil society actors, including previous adversaries like Climate Action Network and Friends of the Earth International, staged a "walk out" of the summit, which is said to have rekindled a sense of solidarity (de Moor 2018; Hadden 2015). A few weeks later, CC21 organized its first meeting to start preparing for COP21. Whatever differences there had been in the various local Copenhagen narratives prior to this meeting, the general sense of defiance that is said to have inspired the meeting, as well as groups' self-selection into this meeting, presumably created fertile ground for the narratives critical of the COP process to prosper. Most likely, the increased communication between different parts of the movement around this time strongly contributed to the convergence around the Copenhagen narrative that was dominant during the preparations for COP21.

Our study starts by identifying how the retrospective "Copenhagen narrative" was recalled in the context of mobilizing for COP21 and how it was integrated into the prospective "Paris narrative." We then show how these narratives - though referring to "real" events-were reconstructed to support strategizing for COP21. We also show how the narrative was contested and why some interpretations came to dominate over others. Finally, we explain how the ways in which political opportunities were narrated affected the adoption of certain strategies over others, while highlighting that some alternative strategies could be advanced without challenging the dominant narrative about the POS.

\section{The dominant Copenhagen narrative}

Throughout their preparations for COP21, organizers attempted to come up with strategies that would be adapted to opportunities and threats expected in Paris. As we see below, a key component of the dominant strategy was to mobilize as a steppingstone for future climate struggles without investing too much effort into influencing the outcome of the summit. The mobilization for COP15 in Copenhagen, 2009 was the essential point of reference for this strategy, which became clear when "Copenhagen" was frequently referred to by actors from across the movement's strategic and political spectrum, and when official meeting summaries adopted it. Often, references were brief but clear, like in this summary of an early CC21 meeting: 
Building on lessons from Copenhagen and following COPs, it has been widely endorsed that we should work out initiatives that will enable us "to have the last word" in Paris. (...) We aim at not being fully dependent on negotiators and heads of state. (Official summary of CC21 meeting, August 2014)

CJA made a similar statement about its aim to avoid repeating Copenhagen. Underlying these brief references was a more elaborate "narrative of defeat" about what happened in 2009, with implications for interpretations of the political context and what this meant in terms of threats and opportunities in Paris. This became clear when activists had more room to elaborate in interviews. An organizer from Alternatiba (which was involved in both CJA and CC21) explained "Copenhagen" as follows:

Interviewer: Do previous experiences with the COP affect how you are mobilizing for COP21?

Respondent: Yes, definitely. (...) Alternatiba is actually answering [to] the (...) consequences of COP15 in Copenhagen where movements adopted a strategy of saying: "Yes this is the COP of the last chance," and thought that by massively mobilizing people they could obtain this dream agreement, you know. And then it didn't work. And after that, the climate movement in Europe completely collapsed and for the coming years it was really impossible to mobilize on climate issues on the massive scale.

And so Alternatiba said: "Yes, we need to change this strategy for COP21 and avoid saying it's (...) the COP of the last chance (...)." But say: "It's a very important summit," and mobilize towards it, but the primary objective will not be to obtain the dream agreement because it is very improbable that it will happen. But instead (...) use it as an opportunity to strengthen the movement and reinforce the capacities of our society to implement the ecological transition. (...) You can call it a realistic mistrust based on the experience of previous COP and also based on a pretty sober assessment of the capacity of social movements to influence the decision-making processes on this international level (...).

Variations of this story are recounted, in more or less detail, throughout many interviews, and it is highlighted with and without the interviewer probing for the role of previous COPs. The experience of Copenhagen was key in informing most activists about the POS surrounding COPs more generally. This is something that also became clear in the many references to Copenhagen in strategic meetings. References made during meetings were never as detailed as the one above. Yet the analysis below will demonstrate that, notwithstanding some important contestations, there is generally strong agreement about the meaning of underlying references to "Copenhagen."

The plot of the retrospective narrative in the first part of the above quote has the following structure: the movement framed Copenhagen as a last chance to save the climate, it was hopeful the summit could deliver, and it thereby managed to mobilize massive protests successfully. Yet the failure of the Summit led to a post-Copenhagen "hangover" or "depression" that demobilized the climate movement. The moral of this story is that the Copenhagen experience falsified the expectation that the UN would be able to draft a strong and binding climate agreement and that pressure by social movements could force leaders to realize this potential, thus debunking a 
predominantly optimistic perception of the COP's POS. The experience taught the organizers that the UN's input structures were closed and, above all, that its output structures were weak.

Corresponding to this narrative, a central goal of the Paris mobilization came to be preventing demobilization. As illustrated by the second half of the last quotation, when a massive mobilization was set in motion for COP21, a core component of the strategy was to maintain low expectations about the outcomes of the summit. Organizers therefore planned to invest little effort in influencing the outcomes of the summit negotiations. They thereby sought to minimize the movement's dependency on the COP and its unfavorable POS. The Paris strategy crucially involved telling a story about the COP21 campaign as the beginning of a long-term climate mobilization and not as a "now or never" moment.

Thus, while the narrative about Copenhagen contained a beginning, middle, and end, it now was applied, in its entirety, as the beginning of a new story. "Copenhagen" defined the COP's POS, which-remaining unchanged - now shaped opportunities for the Paris mobilization. The Paris mobilization functioned as the middle of the story, and the movement after Paris as an (open) end. Figure 2 illustrates the structure of these narratives.

\section{Construction and use of the Copenhagen-narrative}

As pointed out above, the moral of the Copenhagen narrative is rather consistent with scholarly descriptions of the input and output structure of the Copenhagen COP. However, to conclude that the Copenhagen narrative or climate activists' reading of the POS were therefore "neutral" or "objective," would overlook the profound streamlining efforts made to construct this "shared" narrative and its strategic implications. The Copenhagen narrative drew on the collective "experiencing" of the COP15 mobilization (phase 1, Fig. 1), but as we demonstrate in this section, by the time of the COP21 mobilization it had been turned into a shared "experience" (phase 2). Despite contestation, it had also become the main narrative to guide strategizing for the Paris mobilization (phase 3). Particularly as a metonym and a teaching myth, it came to be a way to distinguish insiders and outsiders and to align veterans and newcomers to radicalized strategies.

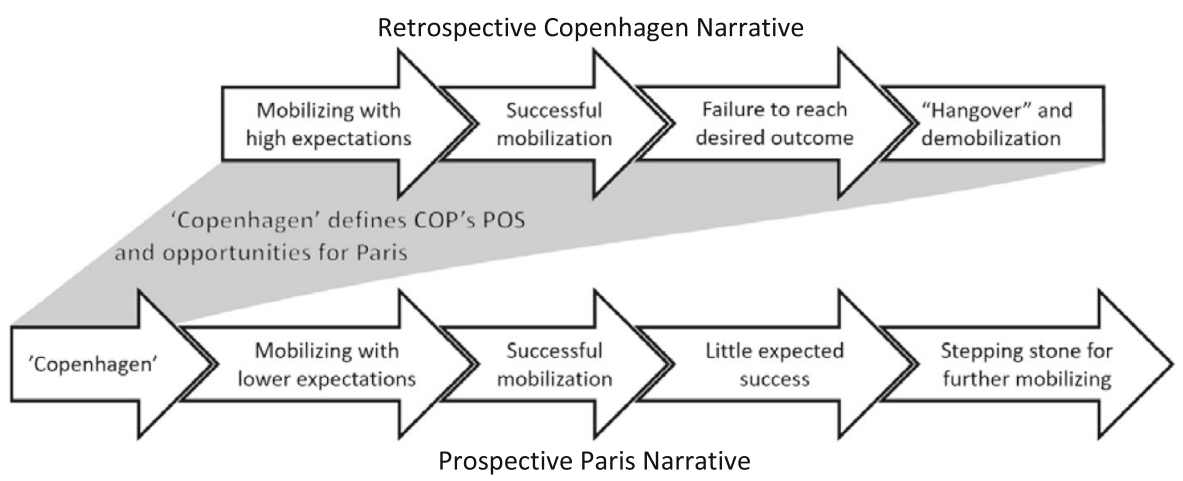

Fig. 2 The "Copenhagen narrative" and its place in the "Paris narrative" 


\section{Streamlining "Copenhagen"}

Even though we lack data from the immediate aftermath of Copenhagen, we have indications to suggest that the Copenhagen narrative was partly reconstructed in relation to the COP21 mobilization, illustrating the feedback-loop between phase 2 and 3 of our model (Fig. 1). Organizers actively streamlined the Copenhagen narrative, as an experienced organizer from Friends of the Earth International recalled:

NGOs had so many different competing messages about Copenhagen, you could just be drowned out and not have any idea. Was it successful or was it not successful? They're telling me it was okay, you're telling me it wasn't, blah blah blah. So, since then we're trying to work on making sure we have a more common narrative. We don't make the mistake of talking about governments and leaders saving this. To talk about people and people's agency and power so there is a narrative to and beyond the COPs. (Interview FoE-I 2015)

The movement indeed developed a "common narrative" about what had happened in Copenhagen, which remained stable and dominant throughout preparations for the Paris mobilization, favoring the radical strategies described above, which depended on "people's agency and power"" not "governments and leaders." However, not all organizers agreed with this narrative. Zooming in on these divergences reveals what streamlining meant more concretely, why some narratives had come to dominate, and what this meant for strategic decisions.

Firstly, some activists claimed that they never had any expectations of the COP15 negotiations in the first place, thus challenging the idea that the hangover originated from dashed hopes. Some interviewees argued that the hangover originated rather from the disappointing mobilizing capacity of the climate justice movement (cf. Bullard and Müller 2012), while one activist explained that he never had any expectations for Copenhagen whatsoever (informal interview ASEED 2016). Others stressed that the problem had been that there were no actions prepared to focus on after the COP. Hence, they shift emphasis to the shortcomings of organizers. Still, these alternative narratives were compatible with the common view that the COP's POS was largely unfavorable, and therefore they did not challenge the movement's concurrent strategic tendency towards ignoring the decision-making process at COP21.

This suggests that stories that emphasize the weakness of the movement, rather than the unfavorability of the POS, may be more likely to be ignored as they paint an unflattering picture of the movement, thereby undermining the need to construct a strong collective identity. By contrast, the story suggesting that the initial misreading of the POS has now been corrected paints a positive picture of a movement that has now become "enlightened." Extending Meyer's (2006) argument that movements tend to claim credit for success, it correspondingly appears to be rational for movements to deflect responsibility for failure. As observed by Voss (1998), movements risk demobilization when they take on responsibility for defeats.

Secondly, some organizers rejected the idea that the Copenhagen Summit was a failure. Particularly those within Avaaz, one of the most resourceful organizations in the coalition, argued that they experienced growth rather than depression or hangover: 
They felt as though they hadn't managed the public expectations going in to Copenhagen. And I think that was a narrative shared by many in the movement. Not our narrative. (...) We took Copenhagen as far as we could take it in that moment. We got leaders there, we got a hundred billion on the table. Didn't get the deal, but we went on to keep fighting. Others took a lesson and (...) one of the lessons I think that came out was that we have to manage public expectations around this stuff. We cannot afford to collapse the movement again. (...) But (...) our members were still engaged in climate. And our community was growing massively after Copenhagen. Donating more money than ever before, people were sharing our campaign more than ever before. (...) So, where is the sense of movement collapse coming from? (...) So, we get to Lima [COP20 2014] (...) and there's a presentation from the French groups [CC21] that the COP is going to be a failure and we have to mobilize at the end of the COP and we shouldn't make it about the COP because we could have the final word and signal to where the movement needs to go next. And we were like, uhm, what?! (Interview 1 AVAAZ 2015)

Rather strikingly, compared to the dominant Copenhagen narrative, which puts emphasis on the unfavorability of the POS, this narrative emphasizes the effectiveness of strategic choices and "claims credit" (see italics above). Likewise, their strategic logic for Paris was one with a positive mobilization message, enough people could be mobilized to force the official negotiations to take them into account, regardless of the POS. When asked about the POS for Paris, another AVAAZ organizer did suggest that opportunities at COP15 had not been as unfavorable as many suggested and looked even brighter at COP21. However, in defending their strategic preferences, they emphasized their mobilizing capacity instead of challenging the Copenhagen narrative.

Consequently, those advocating strategies that would ignore the official climate negotiations could continue to present the canonical Copenhagen narrative as an almost universal truth. Nonetheless, Avaaz, strengthened by its financial wealth and support from trade unions and some other groups in CC21, ultimately managed to undo the exclusive focus on "having the last word." They explained that they would go ahead with their action, with or without coordinating with the coalition's plans. The coalition responded by having two moments of mobilization to retain a unified movement: during the first weekend of the COP, there would be demonstrations aimed at influencing the negotiations, while over the last weekend mobilization would be about condemning the COP's expectedly insufficient outcome or about ignoring the COP altogether.

This development sheds light on the types of resources associated with actors' impact on shaping dominant narratives. Those groups with the greatest financial and material resources at their disposal were able to advance their strategic preferences without having to defend their plans' appropriateness given some narrated POS. In contrast, some of the strongest advocates of the dominant Copenhagen narrative were representatives of smaller, radical groups who had strong impacts on meetings as speakers and brokers, based on their experience and reputation in the movement. Thus, while social capital may increase control over dominant narratives, financial and material capital makes groups able to afford to bypass contestation of narratives.

The reason why wealthy groups did not also challenge the narrative to win even more momentum for their preferred strategy is not entirely clear. Presumably, 
challenging the dominant narrative seemed futile, given its broad resonance among climate activists and, in fact, in the wider public discourse on COP21 in which many commentators called for expectation management after the Copenhagen disappointment. Moreover, the French context played a role in creating an advantage for the dominant narrative. The narrative was already adopted when CC21 was still a strictly French process. Its pessimism corresponds with the fact that French POSs are widely considered to be particularly closed. Accordingly, French social movements have traditionally preferred radical over reformist strategies (Kriesi et al. 1995). In interviews, French chapters of international NGOs, like CAN, described themselves as more radical than international partners. In this context, the narrative depicting the official political process as irresponsive to the movement was particularly likely to catch on. Only when the process became internationalized in August 2014 did some international groups like Avaaz join, after which it contested the initial strategic consensus. Yet the narrative remained unchallenged.

\section{Metonymy and collective identity}

The dominance of the narrative increased further when the word "Copenhagen" (commonly in combination with "hangover" or "depression") became established as a metonym. Organizers used "Copenhagen" to warn about overly optimistic interpretations of the POS and the need to invest in non-COP oriented strategies, without having to explicate exactly what they meant with this reference. As such, the Copenhagen metonymy became a forceful instrument that drove key strategic shifts in the international climate movement away from historically much broader support for reformist strategies targeted at the official negotiations. Some groups, like Avaaz, retained their reformist strategies. Yet others who in Copenhagen had distanced themselves from more radical action in the past (e.g., Greenpeace and CAN) now rallied around the move away from reformist strategies. We see this clearly in the first two quotations in this section (e.g., "no Copenhagen again!"), and throughout strategic discussions in remarks like "If I recall our international meeting, no-one wants to do it like in Copenhagen" (Conference call CC21, November 19, 2014). Thus, by charging brief sentences with complex meaning and authority, metonyms are valuable rhetorical tools during time-constrained strategic negotiation processes.

In the case of "Copenhagen," this effect is further strengthened by the fact that anyone who would challenge the metonymy could be portrayed as naïve. Unlike the ingroup, the out-group failed to learn from the lessons of Copenhagen and it is on a path to repeat their mistakes, thereby even jeopardizing the success of the wider movement. In this sense, the Copenhagen metonym not only established the "truth" about political opportunities in strategic discussions, but also a sense of community and a corresponding threat of exclusion for those challenging it (cf. Fine 1995, p. 134). During a conference call of CC21, Avaaz was criticized for raising hopes around reformist strategies that aimed to push negotiators to sign an effective climate deal. ${ }^{5}$ One organizer claimed that:

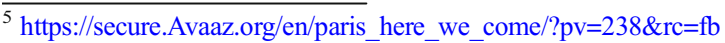


A lot of us are still reeling from the experience of Copenhagen, where in Germany we lost a lot of people for Copenhagen with a completely outside story of what could happen at the summit, e.g., "the climate could be saved there," and "last chance to save the climate." Many of those fell into a years-long (...) "Copenhagen depression," and we are concerned that an Avaaz mobilization with a similar story, "last chance to save the world," will do something similar to our (...) boots on the ground. (Conference call CC21, July 23, 2015)

Thus, beyond strategic adaptation, the Copenhagen narrative also performs "group work" by helping to define the collective's identity: a group that made a mistake once, but in its enlightened form, is now heading towards a brighter future-as distinguished from the unenlightened ones. By advancing a long-term strategy, rather than one oriented towards one moment to save the earth, organizers intended this collective and its identity to last.

\section{"Copenhagen" as a teaching myth}

All social movements have a degree of attrition, and so, veteran activists must educate newcomers about the threats and opportunities derived from their experiences. If streamlining and the establishment of metonyms ensure cross-sectional agreement over a shared narrative, teaching ensures longitudinal agreement. Therefore, to support strategic adaptation further, the Copenhagen narrative was also appropriated as a teaching myth. For example, on the "history" section of its website, CJA writes":

It was clear from the start that we were to learn from our mistakes and not reproduce the "Copenhagen hangover," when back in 2009, people had mobilized together around the COP15, but failed to see beyond it. With the disastrous results that came out of the negotiations, people's energy plummeted and the climate movement was destroyed in many countries.

CJA organizers used a very similar story when they tried to mobilize participants at the anti-nuclear action camp in Bure, France, in August 2015, many of whom had not participated in a COP mobilization before. They explained that the above-mentioned "Red Lines" action they were mobilizing for was designed to prevent the Copenhagen scenario. Furthermore, at a later moment during the meeting, organizers referred attendants to the "Frequently Asked Questions" section of their written action proposal to explain why the Red Lines action would prevent the Copenhagen "syndrome"7:

Q. Doesn't the action place too much emphasis on the talks (a.k.a. Copenhagen syndrome)?

A. We don't agree. We are not cheering negotiators on. This is a more critical engagement than ignoring the talks, and more specific than asking vaguely to "save the climate." This is no Copenhagen moment of falsely raised hope in a flawed process, but a moment of reflection on the reality of what is required and

\footnotetext{
${ }^{6}$ https://climatejusticeaction.net/en/who-are-we/brief-history/

${ }^{7}$ http://www.parisclimatejustice.org/sites/default/files/images/redlinesproposalsept.pdf
} 
how far the world's governments are from it. At least social movements can state the parameters of what's needed. After the talks, whatever is decided, we're all going to have to work together to avoid those red lines being crossed. By clearly stating what is required, and using the action to bring together social movements, we are preparing for action post-COP21.

Once such knowledge is acquired by newcomers, it gives them the ability to defend the appropriateness of their preferred strategies by using "experiences" that derive from likeminded veterans. Indeed, during many strategic meetings, we observed activists who had not shared in the Copenhagen experience recite the logic of preventing its scenario. The Copenhagen narrative, in other words, was rather successful in teaching about threats and opportunities. At the same time, however, knowledge must be simplified and generalized as one generation passes it on to the next, and so the narrative becomes streamlined even further.

\section{Consequences of strategizing based on "Copenhagen"}

Some groups, like Avaaz, maintained their reformist strategies. They believed they had the resources to mobilize enough protesters to force politicians to do the right thing. Their opponents argued, however, that no matter how many resources or participants the movement could mobilize, they could only force the UN to listen-not to become able to act. Input is only relevant if there can be output (de Moor 2016a). Indeed, for many the streamlined Copenhagen narrative motivated a shift away from the reformist tradition, as detailed in the case description above. What form this strategic shift should take remained subject to intense debates, reflecting the diversity of groups aligning with the Copenhagen narrative, including large NGOs, like Greenpeace and Friends of the Earth, and direct action groups like Reclaim the Power and Ende Gelände. As described elsewhere in detail (de Moor 2018), disagreement persisted about who the movement should target instead (national governments, corporations, fellow citizens), how it should do so (through demonstrations, civil disobedience, lifestyle politics, or direct action), and how the actions should be framed.

Starting from a puzzle, we finally assess the main implications of the movement's reliance on narrative to use the Copenhagen experience to inform such strategic shifts. If strategic adaptation to threats and opportunities in the political context is the main goal, it is remarkable that organizers simplified and generalized the Copenhagen narrative considerably. After all, contexts are complex and dynamic, and strategic adaptation would seem to require appreciation of these qualities. Occasionally, more detailed estimations of the POS of COP21 were given, but such detailed accounts never took center stage. It appeared that even though rational calculations were made of the POS, accounts about political opportunities could only influence strategic decision-making processes in the form of rhetorically more efficient stories, with more narrative probability and fidelity (W. R. Fisher 1987), and in its most efficient form, as metonymy.

Turning "Copenhagen" into a shared, simplified and generalized narrative served several key purposes. As we have seen, explaining POSs and opportunities using a basis of experiences added trial and error-based authority to the interpretation. Moreover, developing an understanding of opportunities within the construction of a wider narrative about the movement ensures that perceived opportunities fit the movement's 
sense of origin and direction. Its story-form facilitates teaching newcomers about threats and opportunities. It also allows the movement to turn a "narrative of defeat" into an enthusiastic long-term story about an enlightened movement. Hence, this narrative thereby facilitates strategic adaptation to valuable experiences, by extension strengthening a sense of community and collective identity.

To some extent, this strategy of streamlining seems to have worked. According to one organizer, the movement was indeed able to adapt strategically to prevent a "Paris hangover":

I would say the situation is fundamentally different (...). Copenhagen was a real depression, because people, including myself, had engaged in this kind of magical realism surrounding Copenhagen. You know, suggesting that the event had much more force than it could actually have. But that was not the case for Paris, where some people talked more about Paris, others talked more about Ende Gelände or others like, civil disobedience or divestment. (...) And so, the climate movement had become smarter, broader, more differentiated in terms of their strategies and points of leverage where they could intervene. And so, the Paris result actually wasn't as important for the movement overall (...). There was a lot less magic realism than there was around Copenhagen. (Interview Rosa Luxemburg Foundation, 2016).

The time frames that these narratives cover are crucial. As is evident in the above quotation, preventing the Copenhagen scenario depended on developing a prospective narrative that extended beyond Paris, thereby providing a better rationale for future mobilizations. In contrast, Copenhagen had been depicted as a "last chance." The outcome of the campaign determined the overall success or failure of the movement and the end of the campaign thereby in a sense marked the "end of history," which made further mobilization difficult regardless of the outcome. However, even though the open-ended temporal horizon of the Paris story may have facilitated a focus on long-term mobilization, the "focus beyond Paris" remained rather vague. Looking back on the years following Paris, it is not clear how the COP21 mobilization marked the beginning of a globally coordinated climate movement beyond COPs (de Moor 2018). Moreover, by obscuring the campaign's end point, one also takes away a crucial moment of reflection, and thus, of learning (Beckwith 2015).

Relying on the Copenhagen narrative for strategizing had at least two other limitations: the suppression of alternative readings and retrospective fixation in strategizing. Firstly, because of narrative streamlining, the suppression of alternative stories, the distillation of the dominant story into a convenient metonym, and the loss of detail in teaching newcomers, little attention was given to alternative causes for the Copenhagen hangover. For instance, the above-mentioned interpretation that many activists already expected little from the Copenhagen summit as such, but too much from the movement around it, and that this caused the hangover played a much less central role in reconsidering strategies. Few concerns were raised about whether expectations for new strategies should be managed. Granted, it is difficult to mobilize people on a motivational frame that downplays the potential for success too much (Benford and Snow 2000), and in fact, for some, presenting Paris as a stepping stone in a longer struggle actually was an attempt to manage expectations about the movement itself as 
well. Overall, it is difficult to assess whether organizers portrayed a sufficiently realistic picture of potential success - especially given the unpredictability of the terrorist attacks in Paris two weeks before COP21 and the resulting increase in contextual uncertainty (Wahlström and de Moor 2017). Our point is that by paying significantly more attention to just one reading of the causes of the Copenhagen hangover, the organizers risked not learning from the other readings.

Secondly, relying on experience-based narratives also has risks because of these stories' retrospective nature. Because the opportunities and threats for Paris were estimated based on Copenhagen, new potential opportunities remained largely overlooked. Notably, the shift of the UN climate process from being top-down to becoming more bottom-up could have been, but was not, interpreted as a shift in opportunities. More specifically, with the introduction of Intended Nationally Determined Contributions (INDCs) the UN's focus shifted from drafting a single international policy (like the Kyoto Protocol) to the coordination of nationally determined actions to address climate change (Hale 2016). This devolution of international climate politics could be interpreted as a shift in the POS that meant that most substantive political influence expectedly could be had around the development of INDCs, rather than at the coordination of these commitments during the summit (Bäckstrand et al. 2017; de Moor et al. 2017b).

This shift in the political context was not entirely overlooked. It was often mentioned among organizers that little political influence could be had during COP2 1 because the real political work would already have been done beforehand, through the INDCs and preparatory meetings at the UNFCCC headquarters in Bonn. However, in terms of political opportunities, this was only interpreted as confirmation of the Copenhageninspired idea that no meaningful political influence could be had during COP21, and not as a shift in political opportunities to the national level. Only once, during a CJA meeting in January 2015, did we overhear activists interpreting INDCs as a potential opportunity for the popular mobilization, but this idea did not resonate. An organizer from CAN France expressed concerns about the movement's neglect of INDCs:

One of the main concerns that I have, is why didn't the NGO community inside and outside (...) take a stronger stand on the INDC's? (...) As a movement, we don't have these discussions. (Interview CAN France, 2015)

While being immersed in COP21 activism for two years, we found no evidence for mobilizations to influence INDCs - certainly not from within CC21 and CJA. Some mobilizations took place at the national level in countries around the globe in May 2015, while the INDCs were still being drafted. However, none of them was reported to have targeted the drafting of national commitments, focusing rather on pollution, agro-industry, or fossil-fuel companies. Groups that had a more optimistic reading of Copenhagen also did not act on INDCs, as they preferred to continue targeting the UN negotiations.

We do not know whether the groups in our study had the resources to target INDCs on top of these other mobilizations, or whether doing so would have enhanced the movement's success. It is simply remarkable that this fundamental shift in the POS was not considered as a political opportunity, but only as confirmation of the conclusions drawn from Copenhagen. Those relying on Copenhagen to interpret Paris could 
perceive only those threats and opportunities for which an equivalent existed in 2009. Consequently, a general conclusion to be drawn from these observations is that while narratives about experiences can be effective in ensuring strategic adaptation to POSs, they can cause a retrospective fixation that blinds movements to emerging opportunities. Moreover, this suggests that being able to rely on experience and narrative when considering an opportunity or threat increases the likelihood that such a consideration ultimately affects strategic decisions.

There is, however, also an important exception to this observation. When terror attacks struck Paris just two weeks before COP21, the movement's playing field changed dramatically. As we describe in detail elsewhere (Wahlström and de Moor 2017), the movement showed a large degree of resilience when French authorities responded by installing a state of emergency and a ban on protesting. Although the march planned for the first weekend of the COP was cancelled, other strategies were maintained in adapted forms. Organizers obtained detailed information about the contextual changes and liaised with authorities throughout several weeks of intense adaptations. Concurrently, they made several changes to the actions they planned. The demonstration of the first weekend was cancelled and replaced by a "human chain" along the original itinerary of the march. The location for the Red Lines action was moved from the conference venue to a less sensitive location in the city center of Paris. This shows that changes in the political context were in fact acted upon, and that the Copenhagen experience was not the only source of information used to assess the political opportunities. Nonetheless, adaptations were made at the tactical level only. The strategic logic, inspired by the Copenhagen narrative, remained unchanged. Indeed, while the form of several protests changed, they remained inspired by a sense that the COP's POS was too unfavorable to target. If anything, the attacks, and the subsequent show of force by the French authorities, strengthened this sense. Furthermore, the state of emergency cannot be compared with, e.g., the introduction of INDCs. The former was immediate, dramatic, and essentially impossible to ignore. The latter, while noticed, could be ignored without any immediate consequences.

\section{Discussion and conclusion}

Figure 3 summarizes our main findings regarding the causal mechanisms and conditions that determine how experienced and narrated POSs affect social movement actors' strategic decisions. This process spans three analytically distinct phases, which in reality are intertwined. The (re-)construction of narrated experiences in Phase 2 can only take place once experiencing in Phase 1 has begun and must take place before Phase 3 to inform strategic decision-making. However, we recognize that narration often already begins while experiencing, and can be revisited when strategizing - hence Phase 2's T-shape in the figure. By necessarily simplifying reality, the figure does not capture the possibilities that there are more than two competing perspectives in movements' internal strategizing or that these processes may be constantly interactive (however, see discussion of arrow [E]).

We found that narrated POSs come to affect strategic choices through a number of steps and that, at each step, certain conditions determine the impact of narrated POSs. Firstly, a predominant experience of defeat in Phase 1 creates a greater inclination 


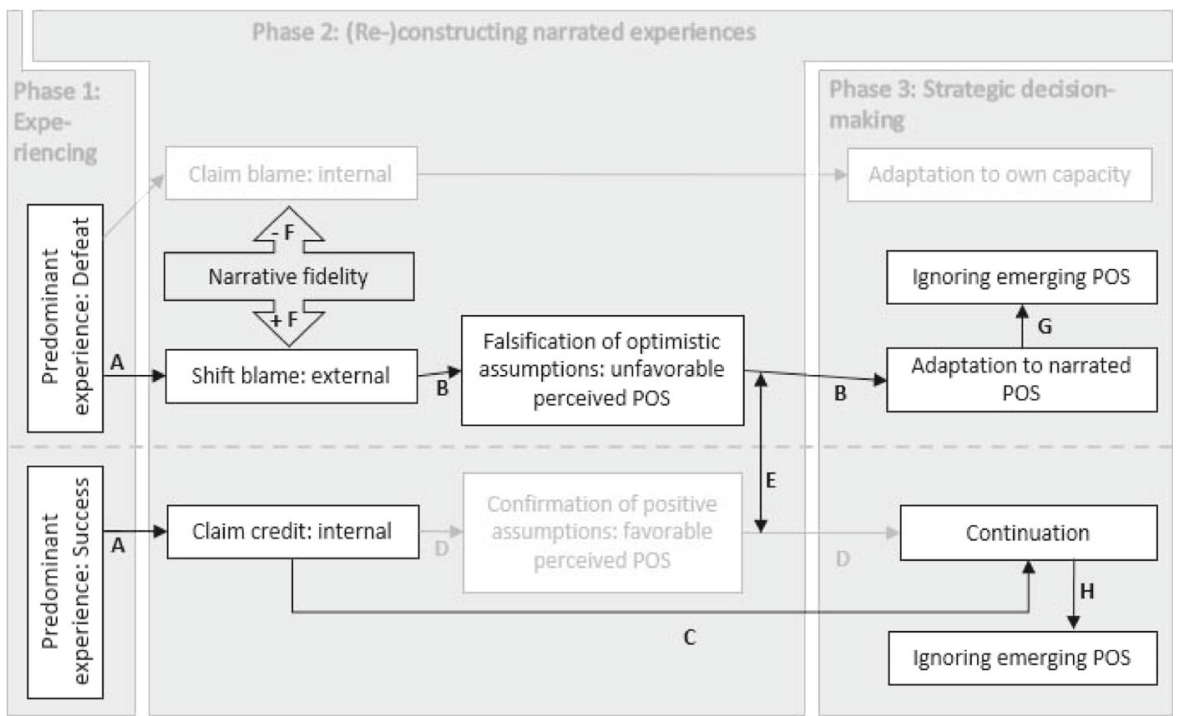

Note: Most likely pathways indicated with black; less likely pathways indicated with grey.

Fig. 3 Causal model outlining how narrated experiences influence strategic decisions

towards an external, rather than internal, attribution of causes of events. That is, in line with Meyer's argument (Meyer 2006) that movements who experienced success have a tendency to claim credit for it, and Voss's (1998) observation that movements who take the blame for their defeats are likely to demobilize, we argue that moving on from defeat likely involves attributing blame to the political context (A). Consequently, those who experience defeat are more likely to rely on reflections on the POS to determine their strategies. More specifically, they will find previously held assumptions about the POS to be false, because overly optimistic, and they will want to adapt strategies accordingly (B). This conclusion qualifies non-reflexive causal models about the POS (e.g., Koopmans 2005). Those who experienced success will more likely choose to continue their strategies (C). If they do reflect on the POS, they are more likely to conclude that their interpretation of the POS was justified (D). Such reflection is most likely to occur when their strategic preference of continuation is challenged by the more pessimistic narratives about the POS of those who advance strategic change, which may of course create feedback $(\mathbf{E})$. Indeed, while there is potential for interaction, discussion, and conflict among various sides of a movement throughout this process, we suggest that the contestation of narrated POSs intensifies when the latter become consequential for strategic discussions - hence its specific articulation in the figure.

In our case, however, this only happened to a limited degree. We found that the availability of particular resources determines actors' reliance on narratives about the POS to convince others about their strategic preferences. Those groups with a more optimistic reading of the POS could rely on their greater control over material resources to determine strategic decisions. In contrast, those with mainly social capital were in a better position to shape broadly shared movement narratives to influence strategy. Presumably, if groups like Avaaz would have had fewer resources at their disposal, they would have been more likely to challenge the Copenhagen narrative. Still, they may have been unlikely to succeed as the dominant Copenhagen narrative had several 
advantages: (1) it could paint itself as "enlightened," thereby putting challengers at risk of being perceived not only as outsiders but also as ignorant; (2) the French context in which the mobilization took place was favorable to the more pessimistic interpretation; and (3) even outside France, its message resonated more broadly, for instance in mainstream media that, based on the experience of Copenhagen, tempered expectations for COP21.

We also found that for those who experienced defeat, narratives about POSs became more important for determining strategic adaptation than narratives that mainly attributed causes for defeat to the movement itself. It appears that narratives that attribute the cause of defeat externally have more narrative fidelity $(\mathbf{F})$, and in turn a greater impact on strategizing, because they contribute towards a more positive collective identity. Other qualities that we found to boost narratives' impact (not in Fig. 3) include rhetorical moves, such as dramatization (hangover, depression, syndrome), and metonymy, by which large amounts of information about complex situations can be reduced to a convenient, authoritative expression, like "Copenhagen." This provides a great advantage in time-constrained strategic meetings and helps to get newcomers up to speed about the contextual appropriateness of particular strategies. Here, we refine Gamson and Meyer's (1996) theory of framed opportunities by showing that, in strategizing, framed opportunities that come with a high degree of narrative fidelity and narrative probability outweigh those without. Moreover, we qualify Gamson and Meyer's suggestion that movements overestimate the favorability of POSs to motivate strategies as our case suggests that narratives attributing failure to unfavorable POSs are particularly influential.

Finally, we found that experience-based strategizing creates a retrospective fixation, as those who experienced defeat adapt to narrated POSs $(\mathbf{G})$, while those who experienced success prefer continuity $(\mathbf{H})$. This can cause emerging opportunities to be overlooked. This point is neglected by those who argue that it is changes in POSs that affect collective action (e.g., McAdam 1982; Tarrow 1989; Tilly 1978), and it could help explain why some studies do not find an immediate effect of changes in POSs on social movements (e.g., Soule et al. 1999): a delay might need to be considered. Another risk is that efficient narratives about opportunities rely on simplification and generalization. This can come at the cost of important details or even of more fundamental insights from alternative readings. Moreover, the power dynamics shaping the narrative in a particular way can frustrate actors who disagree with a particular reading, and while a shared narrative might be a binding factor, it can alienate possibly important allies.

In short, narrated POSs affect strategic decisions mainly among groups who experienced defeat and lack the resources to advance strategic preferences otherwise; they outweigh narratives that attribute the cause for defeat internally; and they outweigh perceptions of emerging opportunities, as these are not supported by trial and error. However, we also found that sudden changes in the political context, such as in our case the French state of emergency, can disrupt the execution of strategic plans. Strategic plans are important, but do not determine collective action in an unmediated fashion.

We built on narrative literature to develop a theoretical model about the role of experiences of success and defeat to link POSs to social movement strategies. We expect that our theory has broad relevance because for many movements narratives of 
success, and particularly of defeat, will be central to the stories they tell about themselves, and we expect that these stories will in turn inform strategic adaptation to the political context. Responding to POSs through narratives is particularly potent because it embeds information about threats and opportunities in an experience-based story about where the movement is coming from, where it is now, and where it should go next. Nonetheless, given the idiosyncrasies of our case, including that we studied a particularly large transnational mobilization, our theory requires testing and elaboration in relation to potentially contrasting cases. We need further research on movements or campaigns that center less on (transnational) mega-events and that are mobilizing on issues that have a temporal structure that differs from irreversible environmental change. We expect analogue, but distinct, mechanisms to be at work in movements or campaigns that care less about the POS, for example, because of expressive orientation or focus on broad cultural change. Movements in less stable contexts may also be less inclined to rely on (narrated) experience to inform strategic decisions.

By proposing a much needed "micro-macro bridge" between political context and activism (Koopmans 2004; Walgrave and Verhulst 2009), our model contributes to the more general understanding of structure and agency in social movements. The basic principles of our model could furthermore yield valuable insights into other types of organizing where strategic adaptation plays a role. Indeed, various recent studies have demonstrated the relevance of the POS approach for a range of actors, such as electoral candidates (Spicer et al. 2017), religious groups (Torrekens and Jacobs 2016), and corporate lobbies (Ehrlich and Jones 2016). There are also growing literatures on organizational sense-making (Maitlis and Christianson 2014) and organizational strategy as practice (Fenton and Langley 2011), which are informed by narrative perspectives.

We recommend that scholars with an interest in strategic adaptation study the use of narratives by agents trying to understand the social, cultural, economic, and political structures in which they act and to which they negotiate strategic responses. Fruitful lines of inquiry include: (1) which actors use which narratives of opportunity structures to advance strategies, (2) how these narratives are constructed and who has the power to shape them, (3) which narratives are ignored and which are taken for granted in the form of metonyms, (4) how narratives link strategizing to identity formation, (5) how narratives of success and of defeat are revisited throughout strategizing, (6) how discursive qualities of the narratives affect strategizing, (7) how alternative strategies are promoted through the use of counter-narratives or otherwise, and (8) whether the use of narratives creates retrospective fixations by which emerging opportunities are overlooked. Lastly, in encouraging further study of how narratives can condition the effect of structures on agency, we also hope to contribute to bridging the gap between structural and cultural approaches to social movements and other forms of organized action.

Acknowledgements The authors would like to thank Mario Diani, Abby Peterson, Håkan Thörn, and Stefaan Walgrave for their constructive feedback on earlier versions of this article. The authors would also like to thank all activists who cooperated in our research and who made this study possible. Part of this research has been made possible by support from the project "Mechanisms of Protest. The Micro-Level Foundations of Individual Protest Participation" (MECPRO), funded by FWO-Flanders, and led by Stefaan Walgrave (University of Antwerp). 


\section{Appendix A}

Selected online and offline observations conducted by the authors

\begin{tabular}{|c|c|c|}
\hline Observed activity & Location & Date \\
\hline Strategy meeting Coalition Climat 21 & Paris & November 11, 2014 \\
\hline Strategy meeting Coalition Climat 21 & Paris & January 15,2015 \\
\hline $\begin{array}{l}\text { Conference call international mobilization } \\
\text { working group Coalition Climat } 21\end{array}$ & Online & January 20, 2015 \\
\hline Strategy meeting Climate Justice Action ${ }^{\mathrm{a}}$ & Brussels & January 30 - February 1, 2015 \\
\hline $\begin{array}{l}\text { Conference call international mobilization } \\
\text { working group Coalition Climat } 21\end{array}$ & Online & February 10, 2015 \\
\hline Strategy meeting Coalition Climat 21 & Paris & February $14-15,2015$ \\
\hline Strategy meeting Climate Justice Action ${ }^{\mathrm{a}}$ & Brussels & March 14-15, 2015 \\
\hline $\begin{array}{l}\text { Conference call international mobilization } \\
\text { working group Coalition Climat } 21\end{array}$ & Online & March 19, 2015 \\
\hline Strategy meeting Coalition Climat 21 & Tunis & March 23-24, 2015 \\
\hline $\begin{array}{l}\text { Conference call international mobilization } \\
\text { working group Coalition Climat } 21\end{array}$ & Online & April 14, 2015 \\
\hline $\begin{array}{l}\text { Conference call international mobilization } \\
\text { working group Coalition Climat } 21\end{array}$ & Online & May 5, 2015 \\
\hline Strategy meeting Coalition Climat 21 & Paris & June $13-14,2015$ \\
\hline $\begin{array}{l}\text { Conference call international mobilization } \\
\text { working group Coalition Climat } 21\end{array}$ & Online & June 30,2015 \\
\hline $\begin{array}{l}\text { Conference call international mobilization } \\
\text { working group Coalition Climat } 21\end{array}$ & Online & July 7, 2015 \\
\hline $\begin{array}{l}\text { Conference call international mobilization } \\
\text { working group Coalition Climat } 21\end{array}$ & Online & July 24,2015 \\
\hline $\begin{array}{l}\text { Conference call international mobilization } \\
\text { working group Coalition Climat } 21\end{array}$ & Online & August 4, 2015 \\
\hline Strategy meeting Climate Justice Action & Bure, France & August 6-8, 2015 \\
\hline $\begin{array}{l}\text { Conference call international mobilization } \\
\text { working group Coalition Climat } 21\end{array}$ & Online & September 1, 2015 \\
\hline Strategy meeting Coalition Climat 21 & Paris & October $2-4,2015$ \\
\hline Strategy meeting Climate Justice Action & Paris & October $10-11,2015$ \\
\hline $\begin{array}{l}\text { Conference call international mobilization } \\
\text { working group Coalition Climat } 21\end{array}$ & Online & October 13, 2015 \\
\hline $\begin{array}{l}\text { Conference call international mobilization } \\
\text { working group Coalition Climat } 21\end{array}$ & Online & November 10, 2015 \\
\hline $\begin{array}{l}\text { Conference call international mobilization } \\
\text { working group Coalition Climat } 21\end{array}$ & Online & November 17, 2015 \\
\hline $\begin{array}{l}\text { Emergency strategy meeting after terrorist } \\
\text { attack, Climate Justice Action and Coalition } \\
\text { Climate } 21\end{array}$ & Paris & November 19, 2015 \\
\hline $\begin{array}{l}\text { Observation of opening weekend actions, including } \\
\text { demonstration Place de la République }\end{array}$ & Paris & November 29, 2015 \\
\hline Various strategic meetings during COP21 & Paris & November 30 - December 9, 2015 \\
\hline
\end{tabular}




\begin{tabular}{|c|c|c|}
\hline Observed activity & Location & Date \\
\hline $\begin{array}{l}\text { Three meetings about the climate movement } \\
\text { beyond COP } 21\end{array}$ & Paris & December 1, 7 and 10, 2015 \\
\hline False solutions COP21 action & Paris & December 4, 2015 \\
\hline $\begin{array}{l}\text { Peoples' Climate Summit and Village of } \\
\text { Alternatives }\end{array}$ & Paris & December 5-6, 2015 \\
\hline $\begin{array}{l}\text { Zone Action Climat, including action } \\
\text { trainings Red Lines }\end{array}$ & Paris & December 7-11, 2015 \\
\hline Red Lines action & Paris & December 12, 2015 \\
\hline $\begin{array}{l}\text { Convergence space Eiffel Tower; action } \\
\text { to have 'the last word' }\end{array}$ & Paris & December 12, 2015 \\
\hline $\begin{array}{l}\text { Climate Justice Action after COP } 21 \text { meeting } \\
\text { to discuss future of the network }\end{array}$ & Amsterdam & January 19, 2016 \\
\hline
\end{tabular}

${ }^{a}$ Climate Justice Action did not have an official name yet during these meetings

\section{Appendix B}

Interviews with organizers conducted by the authors

\begin{tabular}{ll}
\hline Organization & Date \\
\hline Friends of the Earth Europe & November 24, 2014 \\
Friends of the Earth France & November 24, 2014 \\
Climate Express & December 4, 2014 \\
Rosa Luxembourg Foundation & December 4, 2014 \\
Reclaim the Power & January 12, 2015 \\
350.org France & January 20, 2015 \\
Greenpeace France & January 28, 2015 \\
350.org Spain & February 2, 2015 \\
Belgian Climate Coalition & March 3, 2015 \\
Alternatiba & April 4, 2015 \\
Coalition Climat 21 & April 13, 2015 \\
Reclaim the Power & April 20, 2015 \\
Climate Justice Action & April 21, 2015 \\
International Trade Union Federation & April 24, 2015 \\
Greenpeace International & May 14, 2015 \\
Avaaz & June 14, 2015 \\
Ecologistas en acción & June 14, 2015 \\
350.org & June 22, 2015 \\
Climate Action Network France & June 23, 2015 \\
Confédération française démocratique & June 23, 2016 \\
du travail & \\
& \\
\hline Springer & \\
\hline
\end{tabular}




\begin{tabular}{ll}
\hline Organization & Date \\
\hline Alternatiba & June 25, 2015 \\
Grassroots Global Justice Alliance & July 16, 2015 \\
Climate Justice Action/Climate Games & August 6, 2015 \\
Friends of the Earth International & October 10, 2015 \\
Avaaz & October 26, 2015 \\
Agir pour la Paix & December 10, 2015 \\
Coalition Climat 21 & January 18, 2016 \\
Alternatiba & February 2, 2016 \\
Les Désobéissants & April, 2016 \\
Climate Justice Action & April 18, 2016 \\
Rosa Luxembourg Foundation & September 19, 2016 \\
\hline
\end{tabular}

The names of small organizations within Climate Justice Action are not mentioned here, because members of these smaller organizations would otherwise be too easily identifiable

Open Access This article is distributed under the terms of the Creative Commons Attribution 4.0 International License (http://creativecommons.org/licenses/by/4.0/), which permits unrestricted use, distribution, and reproduction in any medium, provided you give appropriate credit to the original author(s) and the source, provide a link to the Creative Commons license, and indicate if changes were made.

\section{References}

Alimi, E. Y. (2009). Mobilizing under the gun: Theorizing political opportunity structure in a highly repressive setting. Mobilization, 14(2), 219-237.

Alimi, Eitan Y., William A. Gamson, and Charlotte Ryan. (2006). "Knowing Your Adversary: Israeli Structure of Political Opportunity and the Inception of the Palestinian Intifada." Sociological Forum 21(4), 535-57.

Armstrong, E. A., \& Crage, S. M. (2006). Movements and memory: The making of the stonewall myth. American Sociological Review, 71(5), 724-751.

Aykut, S. C., Foyer, J., \& Morena, E. (Eds.). (2017). Globalising the climate: COP21 and the Climatisation of global debates. London: Routledge.

Bäckstrand, K., Kuyper, J. W., Linnér, B.-O., \& Lövbrand, E. (2017). Non-state actors in global climate governance: From Copenhagen to Paris and beyond. Environmental Politics, 26(4), 561-579.

Bamberg, M. (2004). Talk, small stories, and adolescent identities. Human Development, 47(6), 366-369.

Beckwith, K. (2015). Narratives of defeat: Explaining the effects of loss in social movements. The Journal of Politics, 77(1), 2-13. https://doi.org/10.1086/678531.

Benford, R. D. (1993). "You could be the hundredth monkey": Collective action frames and vocabularies of motive within the nuclear disarmament movement. Sociological Quarterly, 34(2), 195-216.

Benford, R. D. (2002). Controlling narratives and narratives as control within social movements. In J. E. Davis (Ed.), Stories of change: Narrative and social movements (pp. 53-75). Albany: State University of New York Press.

Benford, R. D., \& Snow, D. A. (2000). Framing processes and social movements: An overview and assessment. Annual Review of Sociology, 26(1974), 11-39.

Blee, K. (2013). How options disappear: Causality and emergence in grassroots activist groups. American Journal of Sociology, 119(3), 655-681.

Boutros, M. (2017). Place and tactical innovation in social movements: The emergence of Egypt' s antiharassment groups. Theory and Society, 46(6), 543-575.

Braun, R., \& Koopmans, R. (2014). Watch the crowd: Bystander responses, trickle-down politics, and xenophobic mobilization. Comparative Political Studies, 47(4), 631-658. 
Brown, K. P. (2016). The prospectus of activism: Discerning and delimiting imagined possibility. Social Movement Studies, 15(6), 547-560.

Bruner, J. S. (1986). Actual minds, possible worlds. Cambridge: Harvard University Press.

Bullard, N., \& Müller, T. (2012). Beyond the "green economy": System change, not climate change? Development, 55(1), 54-62.

Carr, D. (1986). Time, narrative, and history. Bloomington: Indiana University Press.

Daphi, P. (2017). Becoming a movement: Identity, narrative and memory in the European global justice movement. Lanham: Rowman \& Littlefield.

Davis, J. (Ed.). (2002). Stories of change: Narrative and social movements. Albany: State University of New York Press.

de Moor, J. (2016a). The two-dimensional structure of political opportunities: A quantitative and mixedmethods analysis of the effect of political opportunity structures on nonelectoral participation. $\mathrm{PhD}$ dissertation University of Antwerp.

de Moor, J. (2016b). External efficacy and political participation revisited. The role of perceived output structures for state- and non-state oriented action forms. Parliamentary Affairs, 69(3), 642-662.

de Moor, J. (2018). The "efficacy dilemma" of climate activism: The case of COP21. Environmental Politics, 27(6), 1079-1100.

de Moor, J., Marien, S., \& Hooghe, M. (2017a). Why are some lifestyle activists avoiding state-oriented politics while others are not? A case study of lifestyle politics in the Belgian environmental movement. Mobilization, 22(2), 245-264.

de Moor, J., Morena, E., \& Comby, J.-B. (2017b). The ins and outs of climate movement activism at COP21. In S. C. Aykut, J. Foyer, \& E. Morena (Eds.), Globalizing the climate: COP21 and the Climatization of global debates. London: Routledge.

Death, C. (2011). Summit theatre: Exemplary governmentality and environmental diplomacy in Johannesburg and Copenhagen. Environmental Politics, 20(1), 1-19.

Diani, M. (1996). Linking mobilization frames and political opportunities: Insights from regional populism in Italy. American Sociological Review, 61(6), 1053-1069.

Dietz, M. (2014). Debates and conflicts in the climate movement. In M. Dietz \& H. Garrelts (Eds.), Routledge handbook of the climate change movement (pp. 292-307). New York: Routledge.

Ehrlich, S. D., \& Jones, E. (2016). Whom do European corporations lobby? The domestic institutional determinants of interest group activity in the European Union. Business and Politics, 18(4), 467-488.

Eide, E., \& Kunelius, R. (2010). Domesticating global moments: A transitional study on the coverage of the Bali and Copenhagen climate summits. In Global climate, local journalisms: A transnational study of how media make sense of climate summits (pp. 11-50). Bochum: Projekt.

Eisinger, P. K. (1973). The conditions of protest behavior in American cities. American Political Science Review, 67(1), 11-28.

Fenton, C., \& Langley, A. (2011). Strategy as practice and the narrative turn. Organization Studies, 32(9), 1171-1196.

Fine, G. A. (1995). Public narration and group culture: Discerning discourse in social movements. In H. Johnston \& B. Klandermans (Eds.), Social movements and culture (pp. 127-143). London: UCL Press.

Fisher, W. R. (1987). Human communication as narration: Toward a philosophy of reason, value, and action. Columbia: Univ. of South Carolina Press.

Fisher, D. R. (2010). COP-15 in Copenhagen: How the merging of movements left civil society out in the cold. Global Environmental Politics, 10(2), 11-17.

Flyvbjerg, B. (2001). Making social science matter: Why social inquiry fails and how it can succeed again. Cambridge: Cambridge University Press.

Freedman, L. (2015). Strategy: A history. Oxford: Oxford University Press.

Gamson, W. A., \& Meyer, D. S. (1996). Framing political opportunity. In D. McAdam, J. D. McCarthy, \& M. N. Zald (Eds.), Comparative perspectives on social movements. Political opportunity structures, mobilizing structures, and cultural framings (pp. 275-290). Cambridge: Cambridge University Press.

Georgakopoulou, A. (2006). Thinking big with small stories in narrative and identity analysis. Narrative Inquiry, 16(1), 122-130.

Giugni, M. (2009). Political opportunities: From Tilly to Tilly. Swiss Political Science Review, 15(2), 361-367.

Goldstone, J. A. (2004). More social movements or fewer? Beyond political opportunity structures to relational fields. Theory and Society, 33(3-4), 333-365.

Goodwin, J., \& Jasper, J. M. (1999). Caught in a winding, snarling vine: The structural bias of political process theory. Sociological Forum, 14(1), 27-54. 
Hadden, J. (2014). Explaining variation in transnational climate change activism: The role of inter-movement spillover. Global Environmental Politics, 14(2), 7-25.

Hadden, J. (2015). Networks in contention. Cambridge: Cambridge University Press.

Hadden, J. (2017). Learning from defeat: The strategic reorientation of the U.S. climate movement. In C. Cassegård, L. Soneryd, H. Thörn, \& Å. Wettergren (Eds.), Climate action in a globalizing world: Comparative perspectives on social movements in the global north (pp. 125-148). London: Routledge.

Hale, T. (2016). "All hands on deck": The Paris agreement and nonstate climate action. Global Environmental Politics, 16(3), 12-22.

Hale, T., Held, D., \& Young, K. (2013). Gridlock: Why global cooperation is failing when we need it Most. Cambridge: Polity.

Hutter, S. (2014). Protesting culture and economics in Western Europe: New cleavages in left and right politics. Minneapolis: University of Minnesota Press.

Jasper, J. M. (2006). Getting your way. Strategic dilemmas in the real world. Chicago: University of Chicago Press.

Jasper, J. M., Young, M., \& Zuern, E. (2018). Character work in social movements. Theory and Society, 47(1), 113-131.

Johnston, H., \& Klandermans, B. (Eds.). (1995). Social movements and culture. London: UCL Press.

Kitschelt, H. (1986). Political opportunity structures and political protest: Anti-nuclear movements in four democracies. British Journal of Political Science, 16, 57-85.

Klandermans, B. (1997). The social psychology of protest. Oxford: Blackwell.

Koopmans, R. (1999). Political. Opportunity. Structure. Some splitting to balance the lumping. Sociological Forum, 14(1), 93-105.

Koopmans, R. (2004). Movements and media: Selection processes and evolutionary dynamics in the public sphere. Theory and Society, 33(3-4), 367-391.

Koopmans, R. (2005). The missing link between structure and agency: Outline of an evolutionary approach to social movements. Mobilization, 10(1), 19-33.

Koopmans, R., \& Olzak, S. (2004). Discursive opportunities and the evolution of right-wing violence in Germany. American Journal of Sociology, 110(1), 198-230.

Kriesi, H., Koopmans, R., Duyvendak, J. W., \& Giugni, M. (1995). New social movements in Western Europe: A comparative analysis. Minneapolis: University of Minnesota Press.

Kurzman, C. (1996). Structural opportunity and perceived opportunity in social-movement theory: The Iranian revolution of 1979. American Sociological Review, 61(1), 153-170.

Lakoff, G., \& Johnson, M. (2008). Metaphors we live by. Chicago: University of Chicago Press.

Lichterman, P. (2002). Seeing structure happen: Theory-driven participant observation. In B. Klandermans \& S. Staggenborg (Eds.), Methods of social movement research (pp. 118-145). Minneapolis: University of Minnesota Press.

Maitlis, S., \& Christianson, M. (2014). Sensemaking in organizations: Taking stock and moving forward. The Academy of Management Annals, 8(1), 57-125.

McAdam, D. (1982). Political process and the development of black insurgency, 1930-1970. Chicago: University of Chicago Press.

McAdam, D. (1996). Conceptual origins, current problems, future directions. In D. McAdam, J. D. McCarthy, \& M. N. Zald (Eds.), Comparative perspectives on social movements. Political opportunity structures, mobilizing structures, and cultural framings (pp. 23-40). Cambridge: Cambridge University Press.

McAdam, D., \& Boudet, H. (2012). Putting social movements in their place. Cambridge: Cambridge University Press.

Meyer, D. S. (2004). Protest and political opportunities. Annual Review of Sociology, 30(1), 125-145.

Meyer, D. S. (2006). Claiming credit: Stories of movement influence as outcomes. Mobilization, 11(3), 281298.

Meyer, D. S., \& Minkoff, D. C. (2004). Conceptualizing political opportunity. Social Forces, 82(4), 1457-1492.

Meyer, D. S., \& Staggenborg, S. (1996). Movements, countermovements, and the structure of political opportunity. American Journal of Sociology, 101(6), 1628-1660.

Mische, A. (2014). Measuring futures in action: Projective grammars in the Rio +20 debates. Theory and Society, 43(3-4), 437-464.

Müller, M., \& Walk, H. (2014). Democratizing the climate negotiations system through improved opportunities for participation. In M. Dietz \& H. Garrelts (Eds.), Routledge handbook of the climate change movement (pp. 31-43). New York: Routledge.

Nicholls, W. J. (2014). From political opportunities to niche-openings: The dilemmas of mobilizing for immigrant rights in inhospitable environments. Theory and Society, 43(1), 23-49. 
Opp, K.-D. (2009). Theories of political protest and social movements. A multidisciplinary introduction, critique, and synthesis. London: Routledge.

Overby, L. M. (1990). West European peace movements: An application of Kitschelt's political opportunity structure thesis. West European Politics, 13(1), 1-11.

Polkinghorne, D. E. (1988). Narrative knowing and the human sciences. Albany: Suny Press.

Polletta, F. (1998). Contending stories: Narrative in social movements. Qualitative Sociology, 21(4), 419-446.

Polletta, F. (2006). It was like a fever: Storytelling in protest and politics. Chicago: University of Chicago Press.

Polletta, F. (2009). Three mechanisms by which culture shapes movement strategy: Repertoires, institutional norms, and metonymy. In G. M. Maney, R. V Kutz-Flamenbaum, D. A. Rohlinger, \& J. Goodwin (Eds.), Strategies for social change (pp. 43-57). Minneapolis: University of Minnesota Press.

Polletta, F., \& Gardner, B. G. (2015). Narrative and social movements. In D. D. Porta \& M. Diani (Eds.), The Oxford Handbook of Social Movements. Oxford: Oxford University Press.

Schaefer Caniglia, B., Brulle, R. J., \& Szasz, A. (2015). Civil society, social movements, and climate change. In R. E. Dunlap \& R. J. Brulle (Eds.), Climate change and society: Sociological perspectives. Oxford: Oxford University Press.

Somers, M. R. (1994). The narrative constitution of identity: A relational and network approach. Theory and Society, 23(5), 605-649.

Soule, S. A., McAdam, D., McCarthy, J. D., \& Su, Y. (1999). Protest events: Cause or consequence of state action? The U.S. women's movement and federal congressional activities, 1956-1979. Mobilization, 4, 239-256.

Spicer, Z., McGregor, M., \& Alcantara, C. (2017). Political opportunity structures and the representation of women and visible minorities in municipal elections. Electoral Studies, 48, 10-18.

Steinberg, M. W. (1998). Tilting the frame: Considerations on collective action framing from a discursive turn. Theory and Society, 27(6), 845-872.

Suh, D. (2001). How do political opportunities matter for social movements?: Political opportunity, misframing, pseudosuccess, and pseudofailure. The Sociological Quarterly, 42(3), 437-460.

Tarrow, S. G. (1989). Democracy and Disorder: Protest and Politics in Italy, 1965-1975. Oxford: Clarendon.

Tarrow, S. G. (2011). Power in movement. Social movements and contentious politics. Cambridge: Cambridge University Press.

Tatum, J. D. (2002). Compassion on trial: Movement narrative in a court conflict over physicianassisted suicide. In J. E. Davis (Ed.), Stories of change: Narrative and social movements (pp. 179-202). Albany: State University of New York Press.

Thörn, H. (2006). Anti-apartheid and the emergence of a global civil society. London: Palgrave Macmillan.

Tilly, C. (1978). From mobilization to revolution. Reading: Addison-Wesley.

Tilly, C. (2004). Social movements 1768-2004. Boulder: Paradigm.

Torrekens, C., \& Jacobs, D. (2016). Muslims' religiosity and views on religion in six Western European countries: Does national context matter? Journal of Ethnic and Migration Studies, 42(2), 325-340.

van der Heijden, H.-A. (2006). Globalization, environmental movements, and international political opportunity structures. Organization \& Environment, 19(1), 28-45.

Voss, K. (1998). The collapse of a social movement: The interplay of mobilizing structures, framing, and political opportunities in the knights of labor. In M. P. Hanagan, L. P. Moch, \& W. P. Te Brake (Eds.), Challenging authority: The historical study of contentious politics (pp. 136-148). Minneapolis: University of Minnesota Press.

Vráblíková, K. (2014). How context matters? Mobilization, political opportunity structures, and nonelectoral political participation in old and new democracies. Comparative Political Studies, 47(5), 203-229.

Wahlström, M. (2011). Taking control or losing control? Activist narratives of provocation and collective violence. Social Movement Studies, 10(4), 367-385.

Wahlström, M., \& de Moor, J. (2017). Governing dissent in a state of emergency: Police and protester interactions in the global space of the COP. In C. Cassegård, L. Soneryd, H. Thörn, \& $\AA$. Wettergren (Eds.), Climate action in a globalizing world: Comparative perspectives on social movements in the global north. London: Routledge.

Wahlström, M., \& Peterson, A. (2006). Between the state and the market: expanding the concept of political opportunity structure. Acta Sociologica, 49(4), 363-377.

Wahlström, M., \& Törnberg, A. (2019). Social media mechanisms for right-wing political violence in the 21st century: Discursive opportunities, group dynamics, and co-ordination. Terrorism and Political Violence. https://doi.org/10.1080/09546553.2019.1586676.

Walgrave, S., \& Verhulst, J. (2009). Government stance and internal diversity of protest: A comparative study of protest against the war in Iraq in eight countries. Social Forces, 87(3), 1355-1387. 
Publisher's note Springer Nature remains neutral with regard to jurisdictional claims in published maps and institutional affiliations.

Joost de Moor is a postdoctoral researcher at Stockholm University's Political Science Department. He has published on social movements and political participation in various academic journals, such as Acta Politica, Mobilization, Parliamentary Affairs, and Journal of Urban and Regional Research. Related to the current article, he recently published The "efficacy dilemma" of climate activism: The case of COP21 in Environmental Politics (2018), as well as contributions to edited volumes, including Globalizing the Climate (2017, Routledge) and Climate Action in a Globalizing World (2017, Routledge). His PhD dissertation (University of Antwerp) dealt with the composition and causal mechanisms of political opportunity structures. More recently his work has focused on the depoliticization of environmental activism, political consumerism and lifestyle politics. Joost is currently conducting a project on (non-)mobilization around climate adaptation in four European cities and has co-organized an international protest survey of school strikes on climate change in March 2019.

Mattias Wahlström is Associate Professor of Sociology at the Department of Sociology and Work Science, University of Gothenburg. His research mainly relates to social movements, protest, political violence, and state governance of dissent. In addition to a number of publications on the interaction between police and protesters (in, e.g., Mobilization 2007, Environment and Planning D: Society and space 2010, and Social Movement Studies 2011), he has written several articles and book chapters on participation in street protests. With Abby Peterson and Magnus Wennerhag, he recently co-authored the book Pride Parades and LGBT Movements: Political Participation in an International Comparative Perspective (Routledge 2018). Mattias's research on the climate movement began with a survey of participants in demonstrations connected to the UN climate summit in Copenhagen in 2009. He published an analysis of these protesters' prognostic framing, including the prevalence of the "climate justice" frame, in Global Environmental Politics (2013) with Magnus Wennerhag and Chris Rootes. In March 2019, Mattias had a central role in coordinating an international protest survey of schoolchildren striking for the climate. He currently is also conducting research on radical right online counterpublics and links between radical right social media discourse and political violence. 